\title{
Influence of glucocorticoid receptor gene NR3C1 646 C $>$ G polymorphism on glucocorticoid resistance in asthmatics: a preliminary study
}

\author{
NESRINE A. MOHAMED ${ }^{l}$, ASMAA S.M. ABDEL-REHIM ${ }^{2}$, MOHAMED NAZMY FARRES ${ }^{2}$, \\ HEDYA SAID MUHAMMED \\ ${ }^{1}$ Clinical Pathology \& Immunology Faculty of Medicine, Ain Shams University, Cairo, Egypt \\ ${ }^{2}$ Allergy and Clinical Immunology Faculty of Medicine, Ain Shams University, Cairo, Egypt \\ ${ }^{3}$ Chest Diseases Faculty of Medicine, Ain Shams University, Cairo, Egypt
}

\begin{abstract}
Background: Glucocorticoid receptor gene polymorphism (NR3C1 $646 C>G$ ) may play an important role in the development of severe bronchial asthma and resistance to glucocorticoids (GCs).

Objective: The aim of the present study was to determine the relation between the $646 C>G$ polymorphism of the glucocorticoid receptor gene (NR3C1) and resistance to GCs with development of severe bronchial asthma.

Material and methods: This case-control study included 40 patients with severe bronchial asthma and 20 apparently healthy controls. Atopic status was determined by skin prick test reaction to the most common locally-encountered allergens. GCs reversibility test was performed to differentiate between GCs sensitive and GCs resistant asthma. For all subjects, analysis of the glucocorticoid receptor gene polymorphism (NR3Cl $646 C>G$ ) was done using polymerase chain reaction restriction fragment length polymorphism (PCR-RFLP).

Results: The frequencies of NR3C1 $646 C>G$ genotypes and alleles differed significantly between asthmatic patients and controls. The frequencies of the CC genotype and $C$ allele carriers were significantly higher among asthmatics than among controls, and also among GCs sensitive asthmatics than among GCs resistant asthmatics. However, NR3C1 $646 C>G$ genotypes and alleles frequencies did not differ significantly according to the atopic status in asthmatics.

Conclusions: The too small sized of the investigated groups is a shortcoming of this study. Nevertheless, the observed variations demonstrate a marked association of NR3C1 $646 C>G C C$ genotype with the development of bronchial asthma and a higher frequency of the C allele among GCs sensitive asthmatics. Large-scale studies are required to investigate the association between polymorphisms of the NR3C1 gene and GCs resistance among asthmatic patients.
\end{abstract}

Key words: asthma, glucocorticoid receptor, glucocorticoid resistance, restriction fragment length polymorphism, single nucleotide polymorphism.

(Cent Eur J Immunol 2015; 40 (3): 325-330)

\section{Introduction}

Asthma is a chronic inflammatory disease of the airways that is characterized by variable airflow obstruction, increased airway responsiveness and inflammation, mucus overproduction, and airway remodeling [1]. Asthma presents clinically as a result of combination of both genetic and environmental factors, and is the result of disrupted immune regulatory mechanisms occurring at the lympho- cytic level in coordination with excess production of $\operatorname{IgE}$ antibodies resulting in allergic inflammatory reaction [2].

One of the genes involved in the pathogenesis of bronchial asthma is NR3C1; its official name is a nuclear receptor subfamily 3 , group $\mathrm{C}$, member 1 (as determined by HUGO Gene Nomenclature Committee) that encodes glucocorticoid receptor (GCR) [3].

The NR3C1 gene is localized on chromosome $5 \mathrm{q} 31.3$ and consists of nine exons [3]. Exon 1 has seven basic tran-

Correspondence: Dr. Nesrine A. Mohamed, lecturer of Clinical Pathology \& Immunology Faculty of Medicine Ain Shams University, e-mail: alynesrine@yahoo.com 
scriptional variants. Exons from 2 to 8 function as the core sequences of the $\mathrm{NR} 3 \mathrm{Cl}$ gene [4]. Exon 9 determines two alternative splicing variants. The product of NR3C1 gene expression is mRNA, which constitutes the basis for GCR isoforms formed as a result of alternative splicing (GCR $\alpha$, GCR $\beta$, GCR $\delta$, GCR $\gamma$ and GCR-P), among which only the $\alpha$ isoform is active. GCR $\beta$ is able to inhibit the signal pathway of isoform $\alpha$ and lead to impaired sensitivity to glucocorticosteroids [5].

The GCR comprises 777 amino acids and five functional domains(AF1, activation domain 1; DBD, DNA binding domain; HR, hinge region; LBD, ligand-binding domain; and AF2, activation domain 2). The structure and biological activity of GCR domains is determined by the structure and nucleotide composition, among others, of the appropriate/corresponding exons of the NR3C1 gene, respectively: AF1 domain, exon 2; DBD domain, exons 3 and 4; HR and LBD domain, exons 5 to 9. Nucleotide changes in the DNA sequence of the analyzed gene may lead to gene transcription activation disturbances, changes in RNA splicing, changes in the secondary or tertiary structure of GCS receptor domains, translation initiation disturbances and disturbances of GCS receptor mRNA stability $[6,7]$. The interactions of the GC/GCR complex and GC response element (GRE) may lead to selective activation or suppression of the target genes. The effect of GCs on the synthesis of proteins is determined by interactions with transcriptional enhancement sequences (GRE-positive) or transcriptional silencing sequences (GRE-negative). The GCR interacts directly with expression coactivators and corepressors for numerous genes. Therefore, the GCR is a particularly important element determining appropriate patient responses to exogenous GCs, which are the most important anti-inflammatory agents for controlling the course of bronchial asthma [8]. As of today, 2571 polymorphisms of this gene are known, but the most common is the NR3C1 $646 \mathrm{C}>\mathrm{G}$ polymorphism [8]. NR3C1 646 $\mathrm{C}>\mathrm{G}$ polymorphism was identified as a $\mathrm{C} / \mathrm{G}$ substitution in intron 2, 646 nucleotides downstream from exon 2 $[9,10]$. NR3C1 $646 \mathrm{C}>\mathrm{G}$ polymorphism significantly affects the process of alternative $N R 3 C 1$ gene splicing and within that mechanism increases the sensitivity to GCs [11, 12]. Other known SNPs of NR3C1 gene included Tth111I and ER22/23EK, N363S polymorphisms, which are also associated with altered glucocorticoid sensitivity. Tth111I polymorphism (rs 10052957) is located in the area of the NR3C1 gene promoter, 3807 bp upstream from the mRNA start site. It causes a $\mathrm{C}>\mathrm{T}$ substitution in the promoter region, that has been associated with enhanced basal cortisol levels [13]. Yet another polymorphism has been described in exon 2, and it comprises two point mutations in codons 22 and 23 that are separated by $1 \mathrm{bp}$. The mutation in codon 22 is silent (GAG to GAA change, both coding for glutamic acid), whereas the codon 23 change from AGG to AAG results in an amino acid change from arginine to lysine (ER22/23EK) [14]. Another variant is the single nucleotide polymorphism N363S, which is an AAT-to-AGT point mutation in exon 2 causing an asparagine to serine amino acid change in codon 363 [15].

GCs resistant asthma is a complex problem, and to the present date, it is unknown whether it is inherited or acquired, and whether it is dependent on genetic or environmental factors [2].

The aim of the present study was to determine the association between NR3C1 $646 \mathrm{C}>\mathrm{G}$ variation and resistance to GCs with development of severe asthma among Egyptians, a previously unstudied ethnic group.

\section{Material and methods}

This study included 40 adult patients with severe bronchial asthma, who were recruited from the Allergy and Chest Diseases outpatient clinics at Ain Shams University Hospitals, Cairo. Asthma diagnosis was established according to GINA guidelines [16]. All patients were subjected to a detailed medical history, clinical examination, and skin prick test (SPT). Atopy was defined by the presence of at least one positive SPT reaction to common environmental allergens including mites, animal epithelia, pollens, and molds. In addition, glucocorticoid (GCs) reversibility test was performed to differentiate between GCs sensitive and GCs resistant asthma.

\section{Glucocorticoid reversibility test}

This was performed in the Pulmonary Functions Laboratory in Ain Shams University Hospital by spirometry to identify patients with GCs resistant asthma. Spirometry was carried out according to the standards of the European Respiratory Society (ERS) and the American thoracic Society (ATS) [17]. Accordingly, asthmatic patients were subdivided into 2 subgroups: GCs sensitive asthmatic patients $(n=20)$; GCs resistant asthmatic patients $(n=20)$. GCs resistant asthma was defined as the failure of asthmatic patients to show an improvement in the forced expiratory volume in the first second $\left(\mathrm{FEV}_{1}\right)$ by $15 \%$ after an adequate course of GCs (oral prednisolone $40 \mathrm{mg} / \mathrm{d}$ for 2 weeks) despite showing clear reversibility ( $>15 \%)$ to $\beta_{2}$-agonists. On the other hand, GCs sensitive asthma was defined as patients who showed an improvement of $30 \%$ in $\mathrm{FEV}_{1}$ measurements after an equivalent dose of GCs.

Individuals who suffered from medication non-compliance, occupational asthma with ongoing antigenic exposure, gastro-esophageal reflux, aspirin or non steroid anti-inflammatory drugs (NSAIDs) sensitivity, food allergy, irreversible airflow obstruction and underlying systemic vasculitis were excluded from the study. Furthermore, patients using drugs which might induce resistance to GCs (including Rifampicin, Phenobarbital, Phenytoin, Ephed- 
rine) and subjects with signs of viral infections, either generalized, or affecting the respiratory tract were excluded.

The study also included 20 apparently healthy individuals as a control group. All controls had no history of asthma or other allergic diseases and had no first-degree relatives with bronchial asthma or atopic disorders. In addition, all controls had normal spirometric lung functions and negative SPT reactions. An informed consent was obtained from all subjects, and the study was approved by the Research Ethics Committee of the Faculty of Medicine, Ain Shams University.

\section{The glucocorticoid receptor gene polymorphism NR3C1 646 C>G by PCR-RFLP}

This was evaluated for all patients and controls at the Clinical Pathology Department, Ain-Shams University Hospital as follows:

\section{Sampling}

$5 \mathrm{ml}$ of venous blood were collected under aseptic conditions from every patient in a sterile EDTA vacutainer tube.

\section{DNA Extraction}

It was done using the QIAamp DNA Mini Kit supplied by Qiagen (Hilden, Germany). DNA in the sample was liberated using proteinase $\mathrm{K}$ solution and lysis buffer. Released DNA was bound exclusively and specifically to the QIAamp membrane in the presence of binding buffer under appropriate salt and $\mathrm{pH}$ conditions. Denatured protein and other contaminants were removed with several washing procedures. The DNA was then eluted from the membrane with elution buffer.

\section{Polymerase chain reaction}

For detection of NR3C1 $646 \mathrm{C}>\mathrm{G}$ polymorphism whose amplified product is $418 \mathrm{bp}$ fragment, amplification was performed using a thermal cycler Gene Amp PCR system 9700 Applied biosystems. PCR product were carried out in volume of $50 \mu \mathrm{l}$ containing $5 \mu \mathrm{l}$ genomic DNA, $25 \mu \mathrm{l}$ of the ready to use master mix supplied by Qiagen, $2.5 \mu \mathrm{l}(25 \mathrm{pmol})$ of forward primer, $2.5 \mu \mathrm{l}(25 \mathrm{pmol})$ of reverse primer and $15 \mu \mathrm{l}$ of deionized water. Primers used were forward primer (5'-GAG AAA TTCACC CCT ACC AAC- 3') and a reverse primer (5'-AGAGCC CTA TTC TTC AAA CTG- 3'). The test primers were chosen according to Pietras et al. [2] and prepared by Promega (Madison Wi, USA). PCR conditions were an initial denaturation step at $94^{\circ} \mathrm{C}$ for 3 minutes and 30 cycles consisting of denaturation at $94^{\circ} \mathrm{C}$ for 45 seconds, annealing at $60^{\circ} \mathrm{C}$ for 45 seconds, and extension at $72^{\circ} \mathrm{C}$ for 1 minute, then final extension at $72^{\circ} \mathrm{C}$ for 10 minutes.

\section{Restriction fragment length polymorphism}

Restriction digestion of the amplified product was performed using $1 \mu \mathrm{l}$ (10 units/ $\mu \mathrm{l}) \mathrm{Bcl}-1$ restriction enzyme supplied by Promega. The enzyme was added to $5 \mu \mathrm{l}$ of PCR amplified product, $10 \mu \mathrm{L}$ deionized water, $2 \mu \mathrm{l}$ of buffer $(10 \times$ of $60 \mathrm{mM}$ tris-Hcl $)$ and $2 \mu \mathrm{l}$ of acetylated bovine serum albumin (BSA) $(10 \mu \mathrm{g} / \mu \mathrm{l})$, followed by a gentle mix. Then the tubes were placed on a heat block for 2 hours at $50^{\circ} \mathrm{C}$. The enzyme was inactivated at $65^{\circ} \mathrm{C}$ for 15 minutes. As experimental control: no-enzyme "mock" digest was used.

\section{DNA analysis by gel electrophoresis}

Amplified product of DNA samples and restriction fragments were run on 2\% agarose gel (Promega) for 30 minutes at $100 \mathrm{~V}$, stained with ethidium bromide (Amresco, Germany). 100 bp DNA ladder (Promega) was also run to identify the site of bands. The gel was examined under an ultraviolet transilluminator (Biometra, Germany).

Digestion of the amplified product resulted in the following products corresponding to the following 3 genotypes defined according to Pietras et al.: homozygous CC genotype if the band was divided into 2 parts: 263 and 155

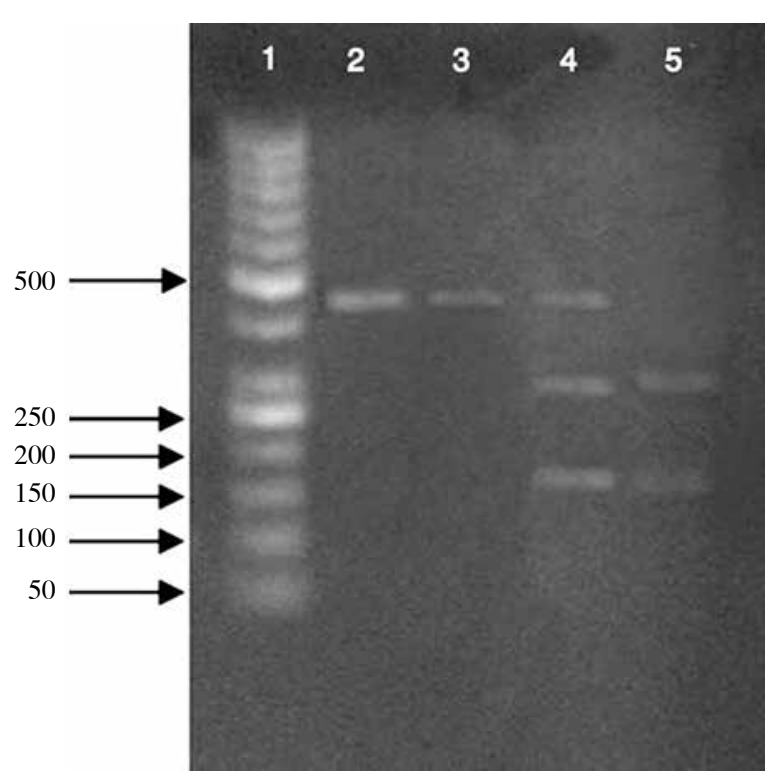

Fig. 1. Agarose gel electrophoresis of NR3C1 $646 \mathrm{C}>\mathrm{G}$ fragments stained with ethidium bromide. Lane 1: $100 \mathrm{bp}$ Ladder. Lane 2 represents unrestricted fragment, 1 band = 418 bp (experimental control: no enzyme "mock"). Lane 3 shows homozygous (GG) genotype, 1 band $=418 \mathrm{bp}$. Lane 4 shows heterozygous (GC) genotype, 3 bands = 418,263,155 bp. Lane 5 shows homozygous (CC) genotype, 2 bands $=263,155 \mathrm{bp}$ 
bp; homozygous GG genotype if the band was not divided: 418 bp; heterozygous GC genotype if it yielded 3 bands: 418, 263 and 155 bp (Fig. 1) [18].

\section{Statistical analysis}

Analysis of data was performed using the SPSS program version 17 . Data were expressed as mean \pm standard deviation (SD) for quantitative parametric measures and both number and percentage for categorical data. Student t-test was used for comparison between two independent groups for parametric data, whereas the one-way analysis of variance (ANOVA) test was used to compare the means of three groups. Comparison between qualitative variables was carried out by using $\chi^{2}$ test and Fisher's exact test. A $p$-value $<0.05$ was considered significant.

\section{Results}

This study included 40 adult patients with severe bronchial asthma (23 females, 17 males). Severe asthmatic patients were subdivided into 2 subgroups: GCs sensitive asthmatic patients, $\mathrm{n}=20$; GCs resistant asthmatic patients $(n=20)$. Age, sex, and the atopic status were comparable among both subgroups. Significantly higher percentages of $\mathrm{FEV}_{1}$ were observed among GCs sensitive asthmatic patients after prednisolone therapy, as compared to GCs resistant asthmatic patients (Table 1).

There was a highly significant difference in frequencies of NR3C1 $646 \mathrm{C}>\mathrm{G}$ genotypes and alleles between asthmatic patients and controls. The CC genotype was more frequent among asthmatic patients than among controls; the GG genotype was more frequent among controls than among asthmatic patients; whereas the GC genotype did not differ in distribution between asthmatic patients or controls. Moreover, almost all controls were $\mathrm{G}$ allele carriers in comparison to about two-thirds of asthmatic patients, whereas almost all asthmatic patients were $\mathrm{C}$ allele carriers (Table 2).

Table 3 shows a significant difference in genotype distribution between GCs sensitive and GCs resistant asthmatics, with a greater frequency of the $\mathrm{CC}$ genotype distribution as well as $\mathrm{C}$ allele carriers among GCs sensitive asthmatics than among GCs resistant asthmatics.

The frequencies of NR3C1 $646 \mathrm{C}>\mathrm{G}$ genotypes and alleles did not differ significantly according to the atopic status in GCs sensitive asthmatics (Table 4) or in GCs resistant asthmatics (Table 5).

Table 1. Characteristics of the study groups

\begin{tabular}{|c|c|c|c|c|}
\hline & $\begin{array}{l}\text { GCs sensitive patient } \\
\qquad(n=20)\end{array}$ & $\begin{array}{l}\text { GCs resistant patients } \\
\qquad(n=20)\end{array}$ & $\begin{array}{c}\text { Controls } \\
(n=20)\end{array}$ & $p$ \\
\hline Age $(y)^{*}$ & $43 \pm 8.2$ & $43 \pm 9.3$ & $40 \pm 5.3$ & 0.410 \\
\hline \multicolumn{5}{|l|}{ Sex, $n(\%)$} \\
\hline Male & $8(40)$ & $9(45)$ & $7(35)$ & 0.337 \\
\hline Female & $12(60)$ & $11(55)$ & $13(65)$ & \\
\hline \multicolumn{5}{|l|}{$\mathrm{FEV}_{1}(\%)^{*}$} \\
\hline Before prednisolone & $57 \pm 4.3$ & $54.3 \pm 4.1$ & - & 0.06 \\
\hline After prednisolone & $76.2 \pm 3.9$ & $56.45 \pm 3.8$ & - & $<0.001$ \\
\hline \multicolumn{5}{|l|}{ Atopic status, $n(\%)$} \\
\hline Atopic & $12(60)$ & $15(75)$ & - & 0.311 \\
\hline Non-atopic & $8(40)$ & $5(25)$ & - & \\
\hline
\end{tabular}

Table 2. Comparison between patients and controls regarding NR3C1 $646 \mathrm{C}>\mathrm{G}$ genotypes and alleles

\begin{tabular}{|c|c|c|c|}
\hline $\begin{array}{l}\text { NR3C1 } 646 \mathrm{C}>\mathrm{G} \\
\text { polymorphism }\end{array}$ & $\begin{array}{l}\text { Patients } \\
(n=40)\end{array}$ & $\begin{array}{l}\text { Controls } \\
(n=20)\end{array}$ & $p$ \\
\hline \multicolumn{4}{|l|}{ Genotypes } \\
\hline GG & $5(12.5)$ & $9(45)$ & \\
\hline GC & $22(55)$ & $10(50)$ & 0.007 \\
\hline $\mathrm{CC}$ & $13(32.5)$ & $1(5)$ & \\
\hline $\mathrm{G}$ allele carriers* & $27(67.5)$ & $19(95)$ & 0.023 \\
\hline $\mathrm{C}$ allele carriers $\mathbb{I}$ & $35(87.5)$ & $11(55)$ & 0.009 \\
\hline
\end{tabular}

Table 3. Comparison between GCs sensitive and GCs resistant asthmatic patients regarding NR3C1 $646 \mathrm{C}>\mathrm{G}$ genotypes and alleles

\begin{tabular}{|c|c|c|c|}
\hline $\begin{array}{l}\text { NR3C1 } 646 \mathrm{C}>\mathrm{G} \\
\text { polymorphism }\end{array}$ & $\begin{array}{l}\text { GCs sensitive } \\
\text { patients } \\
(n=20)\end{array}$ & $\begin{array}{c}\text { GCs resistant } \\
\text { patients } \\
(n=20)\end{array}$ & $p$ \\
\hline \multicolumn{4}{|l|}{ Genotypes } \\
\hline GG & 0 & $5(25)$ & \\
\hline GC & $11(55)$ & $11(55)$ & 0.028 \\
\hline $\mathrm{CC}$ & $9(45)$ & $4(20)$ & \\
\hline $\mathrm{G}$ allele carriers* & $11(55)$ & $16(80)$ & 0.176 \\
\hline $\mathrm{C}$ allele carriers ${ }^{\mathrm{g}}$ & $20(100)$ & $15(75)$ & $<0.001$ \\
\hline
\end{tabular}


Table 4. Comparison between atopic and non-atopic GCs sensitive asthmatic patients regarding NR3C1 $646 \mathrm{C}>\mathrm{G}$ genotypes and alleles

\begin{tabular}{lccc}
\hline $\begin{array}{l}\text { NR3C1 646 C>G } \\
\text { polymorphism }\end{array}$ & $\begin{array}{c}\text { Atopic patients } \\
(\boldsymbol{n}=\mathbf{1 2})\end{array}$ & $\begin{array}{c}\text { Non-atopic } \\
\text { patients }(\boldsymbol{n}=\mathbf{8})\end{array}$ & $\boldsymbol{p}$ \\
\hline $\begin{array}{l}\text { Genotypes } \\
\text { GC }\end{array}$ & $6(50)$ & $5(62.5)$ & \\
CC & $6(50)$ & $3(37.5)$ & 0.362 \\
\hline G allele carriers* & $6(50)$ & $5(62.5)$ & 0.362 \\
\hline C allele carriersI & $12(100)$ & $8(100)$ & 1.0 \\
\hline *Subjects with GG or GC genotypes; "Subjects with CC or GC genotypes All \\
values are presented as number (percentage); GCs, glucocorticoids
\end{tabular}

\section{Discussion}

Despite the fact that GCs are widely used with great success in many inflammatory disorders including bronchial asthma, some patients show poor and sometimes no response to high doses. Difficult-to-treat asthma or GCs resistant asthma is explained by mutations of h-GCR gene, causing impairment of one or more of the molecular mechanisms of h-GR action leading to tissue non-responsiveness to GCs [19].

Polymorphisms present within the h-GR/NR3C1 gene may inhibit formation of GR/GCs complexes, reduce transcription and cause transrepression of the genes encoding proteins synthesized within the framework of cellular response to GCs and decreased expression of GR that leads to a reduced response to GCs and impairment of GCR [20]. GCs resistance is the main obstacle in many inflammatory diseases and therefore makes clinical management difficult [21].

Among the several known functionally relevant alleles of the GCR are the alleles that comprise the NR3C1 646 $\mathrm{C}>\mathrm{G}$. First discovered as a restriction fragment length polymorphism after digestion of GR DNA with $\mathrm{Bcl}-1$, these alleles are determined by a single nucleotide variation - cytosine (most common) or guanine - in intron 2, 646 nucleotides downstream from exon 2 . The allele containing cytosine is referred to as allele $\mathrm{C}$, and the allele containing guanine as allele $\mathrm{G}$, resulting in three possible genotypes at this position: homozygous $\mathrm{CC}$, heterozygous GC and homozygous GG [22].

NR3C1 646 C $>$ G polymorphism significantly affects the process of alternative NR3C1 gene splicing and within that mechanism increases the sensitivity to GCs [18]. However, Manenschijn et al. observed that polymorphism is intronic, and that its location does not involve a coding, regulatory or splicing part of the GCR gene. Additionally, they suggested that this polymorphism is in linkage with other variations, e.g., in the promoter region, or linked to other functionally important polymorphisms [23].

The aim of the present study was to determine the correlation between NR3C1 $646 \mathrm{C}>\mathrm{G}$ single nucleotide polymorphism of h-GR/NR3C1 gene and resistance to
Table 5. Comparison between atopic and non-atopic GCs resistant asthmatic patients regarding NR3C1 $646 \mathrm{C}>\mathrm{G}$ genotypes and alleles

\begin{tabular}{lccc}
\hline $\begin{array}{l}\text { NR3C1 646 C>G } \\
\text { polymorphism }\end{array}$ & $\begin{array}{c}\text { Atopic patients } \\
(\boldsymbol{n}=\mathbf{1 5})\end{array}$ & $\begin{array}{c}\text { Non-atopic } \\
\text { patients }(\boldsymbol{n}=\mathbf{5})\end{array}$ & $\boldsymbol{p}$ \\
\hline Genotypes & & & \\
GG & $4(26.7)$ & $1(20)$ & \\
GC & $7(46.7)$ & $4(80)$ & 0.645 \\
CC & $4(26.7)$ & 0 & \\
\hline G allele carriers* & $11(73.3)$ & $5(100)$ & 0.530 \\
\hline C allele carriers" & $11(73.3)$ & $4(80)$ & 0.999 \\
\hline *Subjects with GG or GC genotypes; "Subjects with CC or GC genotypes \\
\multicolumn{4}{l}{ All values are presented as number (percentage); GCs - glucocorticoids }
\end{tabular}

GCs therapy with the development of severe form/difficult-to-treat asthma. We demonstrated a statistically significant difference in genotype frequencies (GG genotype and CC genotype) of the NR3C1 $646 \mathrm{C}>\mathrm{G}$ polymorphism in all severe asthmatic patients compared with healthy controls; the CC genotype was more frequent in asthmatic patients compared with control subjects, while the GG genotype was less frequent in patients compared with control subjects. This finding is in disagreement with that observed by Pietras et al. who studied a group of Polish patients with severe asthma and observed significant differences between the investigated genotypes with a significant increase in the GG genotype among severe asthmatic patients compared to controls [2].

Our findings are in line with Panek et al. who demonstrated a lower frequency of the NR3C1 646 C > G GG homozygote and a higher frequency of the $\mathrm{CC}$ homozygote among asthmatics (which included mild, moderate, and severe asthmatics) in comparison to the control group. However, the authors observed no statistically significant differences in frequencies of NR3C1 $646 \mathrm{C}>\mathrm{G}$ polymorphism when severe asthma was compared with the control group [18]. The discrepancy between their findings and our results may be attributed in part to our relatively smaller sample size.

In the present study, there was a significant difference in allelic frequencies of the NR3C1 $646 \mathrm{C}>\mathrm{G}$ polymorphism in asthmatic patients compared to controls. $\mathrm{C}$ allele carriers were more frequent among asthmatic patients, whereas $\mathrm{G}$ allele carriers were more frequent among healthy controls. This finding is in contrast with that observed by Pietras et al. who observed a significant difference in allelic frequency regarding the $\mathrm{G}$ allele between asthmatic patients and controls but no significant difference in allelic frequency regarding the $\mathrm{C}$ allele between asthmatic patients and controls.

In addition, the current study showed a significant difference in NR3C1 $646 \mathrm{C}>\mathrm{G}$ genotypes and alleles frequencies between GCs sensitive and GCs resistant asthmatics. We demonstrated that GCs sensitive asthmatics had a greater frequency of the $\mathrm{CC}$ genotype distribution as well as $\mathrm{C}$ allele 
carriers than GCs resistant asthmatics. This finding is also in contrast with that observed by Pietras et al., who demonstrated that allele $\mathrm{G}$ is particularly associated with sensitivity to GCs, and that it increases the cellular response to GCs and occurs less frequently than allele $C$ [2]. This discrepancy could be attributed to different population ethnicity.

Atopy is considered one of the important risk factors in the pathogenesis of asthma. In turn, antigen-specific IgE produced in a sequence of immune processes is essential for atopy to occur. One review explained the role of environmental agents in the modulation of these immune processes, and therefore, modulation in asthma development [24]. The few studies available on the association between NR3C1 $646 \mathrm{C}>\mathrm{G}$ single nucleotide polymorphism of h-GR/NR3C1 gene promoter and resistance to GCs therapy with development of severe form/ difficult-to-treat asthma have not addressed the relationship with atopy. To our knowledge, we report here for the first time that there is no relationship between atopy and this gene polymorphism. Further large-scale studies on larger numbers of atopic asthmatics should be carried out to investigate this relationship.

\section{Conclusions}

The presented study is a preliminary stage for more profound analysis of association between the prevalence of the particular allelic variants of the h-GR/NR3C1 gene and the development of bronchial asthma, including severe, treatment-resistant forms of the disease. It should be emphasized that no studies concerning the frequency of h-GR/NR3C1 glucocorticoid receptor gene polymorphisms in atopic asthmatics patients have been conducted to date.

\section{The authors declare no conflict of interest.}

\section{References}

1. Bousquet J, Mantzouranis E, Cruz AA, et al. (2010): Uniform definition of asthma severity, control, and exacerbations: document presented for the World Health Organization Consultation on Severe Asthma. J Allergy Clin Immunol 126: 926-938.

2. Pietras T, Panek M, Tworek D, et al. (2011):The Bcl I single nucleotide polymorphism of the human glucocorticoid receptor gene h-GR/NR3C1 promoter in patients with bronchial asthma: pilot study. Mol Biol Rep 38: 3953-3958.

3. Kino T, De Martino M, Charmandari E, et al. (2003): Tissue glucocorticoid resistance/hypersensitivity syndromes. J Steroid Biochem Mol Biol 85: 457-467.

4. Bamberger C, Bamberger A, de Castro M, et al. (1995): Glucocorticoid receptor beta, a potential endogenous inhibitor of glucocorticoid action in humans. J Clin Invest 95: 2435-2441.

5. Ito K, Chung K, Adcock I (2006): Update on glucocorticoid action and resistance. J Allergy Clin Immunol 117: 522-543.

6. Beato M, Chalepakis G, Schauer M, et al. (1989): DNA regulatory elements for steroid hormones. J Steroid Biochem Mol Biol 32: 737-747.
7. Panek M, Pietras T, Kupryś-Lipińska I, et al. (2010): The analysis of the factors influencing the development of glucocorticoid resistance in the etiopathogenesis of severe bronchial asthma. Postepy Biochem 56: 373-382.

8. Kmyta V, Prystupa L (2015): Influence of Bcl-1 gene polymorphism of glucocortucoid receptor on phenotypic expressions of bronchial asthma. Clin Transl Allergy 5: 10.

9. Van Rossum E, Koper J, van den Beld A, et al. (2003): Identification of the BclI polymorphism in the glucocorticoid receptor gene: association with sensitivity to glucocorticoids in vivo and body mass index. Clin Endocrinol 59: 585-592.

10.Derijk R, de Kloet E (2008): Corticosteroid receptor polymorphisms: determinants of vulnerability and resilience. Eur J Pharmacol 583: 303-311.

11.Nicolaides N, Galata Z, Kino T, et al. (2010): The human glucocorticoid receptor: molecular basis of biologic function. Steroids 75: 1-12.

12.De Iudicibus S, Franca R, Martelossi S, et al. (2011): Molecular mechanism of glucocorticoid resistance in inflammatory bowel disease. World J Gastroenterol 17: 1095-1108.

13. Rosmond R, Chagnon YC, Chagnon M, et al. (2000): A polymorphism of the 5'-flanking region of the glucocorticoid receptor gene locus is associated with basal cortisol secretion in men. Metabolism 49: 1197-1199.

14.van Rossum EF, Koper JW, Huizenga NA, et al. (2002): A polymorphism in the glucocorticoid receptor gene, which decreases sensitivity to glucocorticoids in vivo, is associated with low insulin and cholesterol levels. Diabetes 51:31283134.

15. Koper JW, Stolk RP, de Lange P, et al. (1997): Lack of association between five polymorphisms in the human glucocorticoid receptor gene and glucocorticoid resistance. Hum Genet 99:663-668.

16. Global Strategy for Asthma Management and Prevention (2009): Global Initiative for Asthma (GINA) NHLB. Available at http://www.ginasthma.org/accessed March 2015.

17. Miller MR, Hankinson J, Brusasco V, et al. (2005): ATS/ERS Task Force. Standardisation of spirometry. Eur Respir J 26: 319-338.

18. Panek M, Pietras T, Fabijan A, et al. (2013): Effect of glucocorticoid receptor gene polymorphisms on asthma phenotypes. Exp Ther Med 5: 572-580.

19. Charmandari E, Kino T, Ichijo T, et al. (2008): Generalized glucocorticoid resistance: clinical aspects, molecular mechanisms, and implications of a rare genetic disorder. J Clin Endocrinol Metab 93: 1563-1572.

20. Maltese P, Canestrari E, Palma L, et al. (2009): High resolution melting (HRM) analysis for the detection of ER22/23EK, BclI, and N363S polymorphisms of the glucocorticoid receptor gene. J Steroid Biochem Mol Biol 113: 269-274.

21. Kostik MM, Klyushina AA, Moskalenko MV, et al. (2011): Glucocorticoid receptor gene polymorphism and juvenile idiopathic arthritis. Pediatr Rheumatol Online J 9: 2.

22.DeRijk RH, Schaaf M, de Kloet ER (2002): Glucocorticoid receptor variants: clinical implications. J Steroid Biochem Mol Biol 81: 103-122.

23. Manenschijn L, van den Akker EL, Lamberts SW, et al. (2009): Rossum EF. Clinical features associated with glucocorticoid receptor polymorphisms. An overview. Ann N Y Acad Sci 1179: 179-198.

24.Peden DB (2000): Development of atopy and asthma: candidate environmental influences and important periods of exposure. Environ Health Perspect 108: 475-482. 